\title{
EFFECT OF THE LEAF Pettiveria alliacea EXTRACT ACTIVE COMPOUND ON Mycobacterium tuberculosis
}

\author{
Ratna Sofaria Munir, Nurmawati Fatimah, Bambang Hermanto \\ Department of Pharmacology and Therapeutics, Faculty of Medicine, Airlangga University
}

\begin{abstract}
ABSTRAK
Indonesia mempunyai berbagai tanaman ramuan yang dijadikan obat herbal/tradisional. Singawalang (Petiveria alliacea) adalah salah satu dari tanaman herbal yang biasanya digunakan di Amerika sebagai obat batuk karena efek ekspektorannya. Tanaman Singawalang juga banyak dipakai untuk menyembuhkan Tuberkulosis. Namun, investigasi mengenai efek toksisitas pada ekstrak daun tanaman ini belum banyak dilakukan. Penelitian ini bertujuan untuk menginvestigasi efek senyawa aktif tanaman singawalang terhadap mikobakteria tuberkulosis menggunakan berbagai macam pelarut. Senyawa aktif ekstrak etanol didapat dengan maserasi menggunakan pelarut etanol. Ekstrak tersebut kemudian difraksinasi menggunakan metode kromatografi kolom, menggunakan eluen secara bertingkat sehingga menghasilkan fraksi. Dosis yang digunakan adalah 0,5 mg/ml; $1 \mathrm{mg} / \mathrm{ml} ; 2 \mathrm{mg} / \mathrm{ml} ;$ Etanol 70\%, hheksana, benzena, kloroform, etilasetat, silika gel 60GF254, Middlebrook 7H9, dan 7H10. Reaksi menggunakan ekstrak daun singawalang dengan berbagai pelarut menghasilkan penurunan jumlah pertumbuhan koloni mikrobateria tuberkulosis, berbeda dengan reaksi pada perlakuan kontrol, perlakuan dengan DMSO 1\%, dan perlakuan dengan Etanol 70\%. Simpulan, berbagai pelarut yang digunakan tidak memberikan perbedaan yang bermakna, namun berbeda dengan perlakuan kontrol, perlakuan dengan DMSO 1\% dan dengan Etanol 70\% yang memberikan hasil yang cukup signifikan. (FMI 2017;53:108-112)
\end{abstract}

Kata kunci: Singawalang (Petivera alliacea), senyawa aktif Singawalang, mikobakteria tuberkulosis

\begin{abstract}
Indonesia has a variety of herbal plants used as herbal/traditional medicines. Singawalang (Petiveria alliacea) is one of the herbal plants usually used in the United States as a cough medicine because of its expectorant effect. Singawalang plants are also widely used to cure tuberculosis. However, the investigations on the effects of toxicity on this plant leaf extract has not been done. This study aims to investigate the effects of active compounds in singawalang against Mycobacterium tuberculosis using a variety of solvents. The active compound of ethanol extract was obtained by maceration using ethanol solvent. The extract was then fractionated using column chromatography method, and using gradual eluent to produce fraction. The doses used were $0.5 \mathrm{mg} / \mathrm{ml} ; 1 \mathrm{mg} / \mathrm{ml} ; 2 \mathrm{mg} / \mathrm{ml}$; $70 \%$ ethanol, h-hexane, benzene, chloroform, ethylacetate, silica gel 60GF254, Middlebrook 7H9, and 7H10. The reactions using Singawalang leaf extract with various solvents resulted in a reduction of the Mycobacterium tuberculosis colony growth, compared with the reaction on control treatment, treatment using DMSO 1\%, and treatment using $70 \%$ ethanol. As a conclusion, the various solvents used did not make a significant difference. However, control treatment, treatment using DMSO 1\%, and treatment using 70\% ethanol had significant results. (FMI 2017;53:108-112)
\end{abstract}

Keywords: Singawalang (Petivera alliacea), singawalang active compound, Mycobacterium tuberculosis

Correspondence: Ratna Sofaria Munir, Department of Pharmacology and Therapeutics, Faculty of Medicine, Airlangga University, Jalan Prof dr Moestopo 147, Surabaya 60131, Indonesia.

\section{INTRODUCTION}

The number of people with tuberculosis in the world is 8.7 million. The number of new patients is $3.7 \%$, and $20 \%$ of those treated have double resistance to antibiotics. The highest number of sufferers in Asia is $59 \%$, followed by Africa 26\%, Middle East 7.7\%, Europe $4.3 \%$ and America 3\%. In Asia, India is in the first position (2-2.5 million cases), followed by Indonesia (0.658-1.450 million cases), China (0.788 to 1.060 million cases), Nigeria (0.345-0.88 million cases), and Pakistan (0.330-0.729 cases ) (WHO 2016).
One cause of death in patients with tuberculosis is due to the presence of Mycobacterium tuberculosis resistance. This resistance is the one that occurs to vari-ous combinations of antibiotics called Multi Drug Resistent (MDR) tuberculosis. The rates of MDR inci-dence in the world are $2.1-5.2 \%$ in new cases and $13-26 \%$ in patients who have received antibiotic therapy. There is 6.7-11.2\% XDR-TB cases in the world. The MDR case in Indonesia is around $9.9 \%$. MDR is more difficult to treat. The cure rate is only $50 \%$. The symptoms of resistant $\mathrm{TB}$ are similar to those of regular $\mathrm{TB}$, but the patients are not improved with TB treatment. Treatment failure will take the patient to the next stage, which is the Extreme Drug Resistant (XDR). XDR is 
an MDR condition with resistance to three or more second-line drugs. XDR makes patients more susceptible to bacteria that have no cure at all (Aditama 2006, WHO 2012). Since the morbidity and mortality rates due to tuber-culosis and resistance of $\mathrm{M}$. tuberculosis bacteria to antibiotics that already exist are high, thus research needs to be done to identify active ingredient as anti $M$. tuberculosis so that health problems, especially tuberculosis and resistant disease, can be overcome more easily.

Singawalang (Pettiveria alliacea) is one of the plants that have activity as anti fungi and anti S. aereus bacteria (Kim 2006). The ethanol extract of Singawalang leaves may inhibit the growth of tuberculosis bacteria. Singawalang leaf extract at a dose of 15 $\mathrm{mg} / \mathrm{ml}$ already has the ability to inhibit Mycobacterium tuberculosis. These data suggest that ethanol extract contains active ingredients that may kill or inhibit the growth of Mycobacterium tuberculosis. Therefore, it is necessary to do research on the isolation of active compounds contained in leaves Singawalang (Pettiveria alliacea) as antibiotics against Mycobacterium tuberculosis.

\section{MATERIALS AND METHODS}

This was a laboratory experimental study. The study design used was post test only control group design. The experimental unit in this study was Mycobacterium tuberculosis strain $\mathrm{H} 37 \mathrm{Rv}$ obtained from ITD UA Tuberculosis Laboratory. The replication of experimental treatment was determined according to the formula by Federer, and there were six treatments used, including control treatment. This study used four repetitions. The independent variable was the dose of active compound from fractionation extract, while the dependent variable was the number of Mycobacterium tuberculosis strain H37Rv.

Singawalang leaves were taken from the area of Balai Materia Medika, Batu, Malang and has been subjected to determination. The plant is grown on plateau with altitude of 800 meters above sea level and harvested at the age between 2-3 months. Extraction and isolation of the Mycobacterium tuberculosis bacterial strain used Middlebrook 7H9 and 7H10 culture media in incubation temperature of 37 degree $\mathrm{C}$, within $\mathrm{CO} 2$ incubator for eight weeks. The active compound of ethanol extract was taken by extraction using macer-ation with ethanol solvent. The extract was then fractionated by using column chromatography method, and using gradual eluent to produce fraction. The doses used were $0.5 \mathrm{mg} / \mathrm{ml} ; 1 \mathrm{mg} / \mathrm{ml} ; 2 \mathrm{mg} / \mathrm{ml} ; 70 \%$ ethanol, $\mathrm{n}$ hexane, benzene, chloroform, ethylacetate, silica gel
60GF254, Middlebrook 7H9, and 7H10. The Mycobacterium tuberculosis used was H37RV strain obtained from Tuberculosis Laboratory of Tropical Disease Institute, Airlangga University. The bacteria extracted from the bacterial Mycobacterium tuberculosis stock was grown on LJ Media for 2-3 weeks.

The extraction was done by maceration in which the Singawalang leaf was soaked in $70 \%$ ethanol solvent. The powder was immersed in a closed vessel for 24 hours at room temperature while stirred frequently. The bath was filtered using buchner filter and vacuum extractor. The filtrate was collected, and the residue was re-immersed with new $70 \%$ ethanol solvent. The extraction process was carried out until the terpenoid compound contained in the leaf extract of Singawalang was undetectable by using thin layer chromatography (TLC) method. The filtrate of the maceration was then evaporated using rotavapour until the viscous extract was obtained. The solvent remaining in the viscous extract was evaporated in acid cabinet. The result was called ethanol extract of Singawalang leaf.

The ethanol extract of Pettiveria alliacea leaf was fractionated by silica gel column chromatography using multilevel eluents, i.e. sequentially starting with n-hexane; n-hexane: benzene (1:1), benzene, benzene; chloroform (1:1), chloroform, chloroform: ethyl acetate $(1: 1)$, ethyl acetate, ethyl acetate; ethanol (1:1) and ethanol.

Every $50 \mathrm{ml}$ of eluate, or fraction that came out, was collected in bottle, then each fraction was evaporated until the solution was $5 \mathrm{ml}$ left. Each fraction was analyzed using TLC, then emerging stains were visible with UV lamp. Fractions that showed stains with the same color and Rf value were combined. Furthermore, each combination activity was examined. The concentrations used for each fraction were $0.5 \mathrm{mg} / \mathrm{ml}, 1$ $\mathrm{mg} / \mathrm{ml}$ and $2 \mathrm{mg} / \mathrm{ml}$ of $100 \mathrm{ul}$.

The most active fraction would be purified again by fractionation using column chromatography and chloroform eluent: ethanol $(1: 2)$. Each $10 \mathrm{ml}$ fraction was collected in bottle, then evaporated to $3 \mathrm{ml}$, and each was analyzed by TLC. Every fraction that ex-hibited stain with the same color and Rf value was combined and tested for its activity against Myco-bacterium tuberculosis.

The number of bacterial colonies grew on $7 \mathrm{H} 10$ medium at various concentrations of active compound of ethanol extract of singawalang leaf. The data collection procedure to identify the presence of bacterial colony growth in the media was carried out with reference to the dilution method. 
The steps were started by incorporating each treatment into liquid medium of $7 \mathrm{H} 9$ Middlebrook containing $105 \mathrm{CFU} / \mathrm{ml}$ germs, then it was incubated in $\mathrm{CO} 2$ incubator for three days. Then it was taken $10 \mu \mathrm{l}$ of every treat-ment, inoculated on Middlebrook $7 \mathrm{H} 10$ solid medium, and incubated in $\mathrm{CO} 2$ incubator during four weeks. Each treatment was repeated three times. The data obtained were on the growth of bacterial colonies occurring at certain dose and was compared with control treatment. Furthermore, the number of colonies in each treatment was calculated, and the decrease in every concentration was examined.

\section{RESULTS}

The conducted study had results as follows:

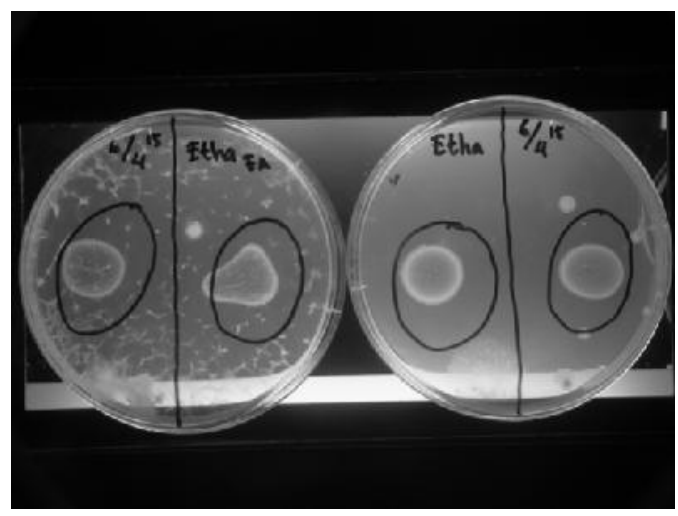

Fig. 1. Results with ethanol and ethyl acetate ethanol solvents

The number of germs that grew on positive control was 87 and on extract administration with ethanol solvent was 64. The number of germs that grew on positive control was 68 and on extract administration with ethyl acetate ethanol solvent was 44 .

The number of germs that grew on positive control was 63 and on extract administration with benzene solvent was 28 . The number of germs that grew on the positive control was 45 and on the extract administration with benzene chloroform solvent was 14 .

The number of germs that grew on positive control was 18 and on extract administration with ethyl acetate solvent was 12 . The number of germs that grew on positive control was 52 and on extract administration with chloroform ethyl acetate solvent was 23 .

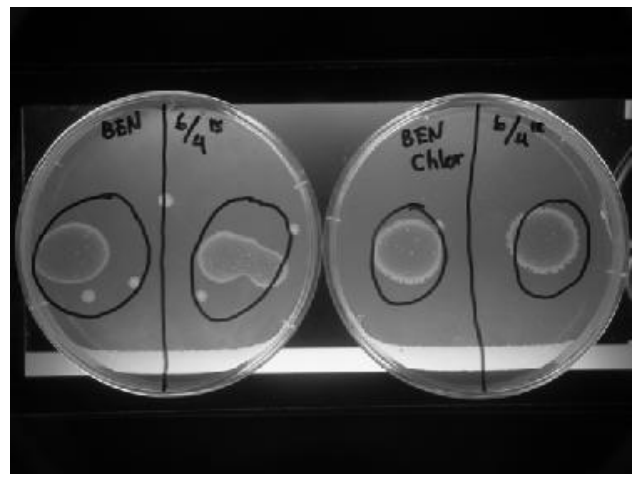

Fig. 2. Results with benzene and benzene chloroform solvents

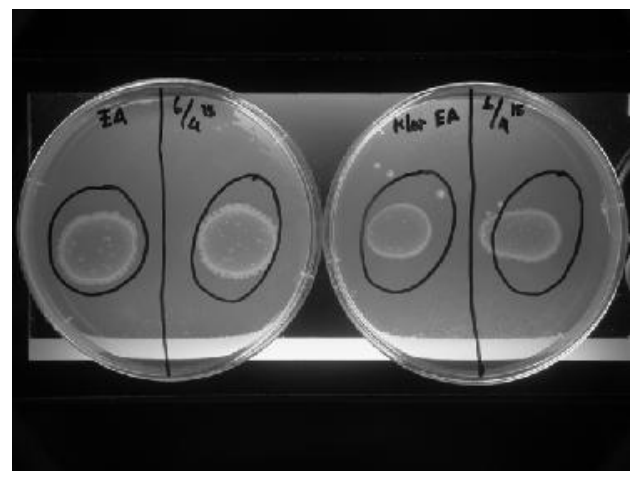

Fig. 3. Results with ethyl acetate and chloroform ethyl acetate solvents

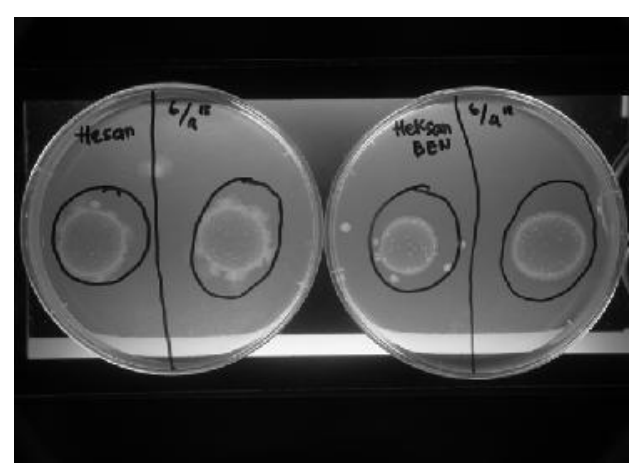

Fig. 4. Results with hexane and hexane benzene solvents

The number of germs that grew on positive control was 47 and on extract administration with hexane solvent was 26. The number of germs that grew on positive control was 31 and on extract administration with hexane benzene solvent was 17 . 
The number of germs that grew on positive control was 63 and on extract administration with DMSO 1\% was 48.

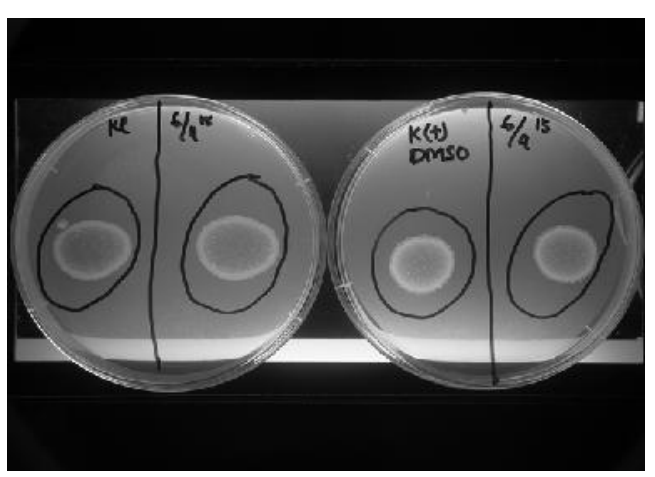

Fig. 5. Results of positive control and control + DMSO $1 \%$

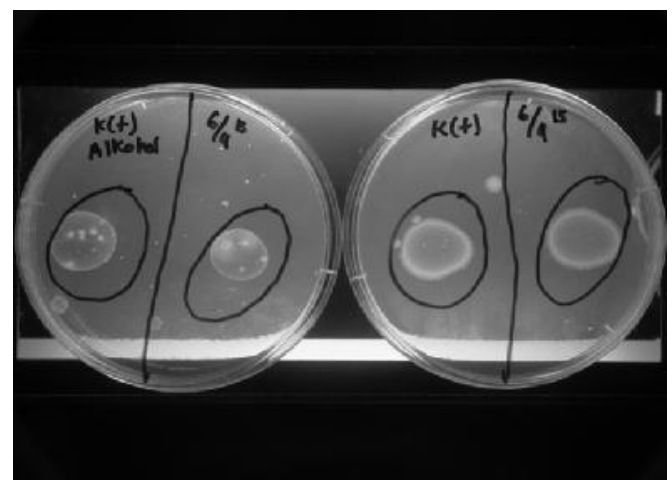

Fig. 6. Results of positive control and kontrol $+1 \%$ alcohol

The number of germs that grew on positive control was 21 and on the extract administration with $1 \%$ alcohol was 18 . This study made four replications that the media image results of each replication were not much different. The solvent used in singawalang leaf extract (DMSO 1\%) did not affect the growth of Mycobacterium tuberculosis.

\section{DISCUSSION}

The main characteristic of tuberculosis is its resistance to acidic laxatives. The resistance of bacteria to acids is due to the presence of waxy coating on the cell wall. It also causes TB bacteria to have stronger natural endurance than other non-spore-forming bacteria, and with sunlight or heat, bacteria will die within a few minutes.

Pettiveria alliacea leaf contains amino sulfur, including benzylcysteine sulfoxides. Sulfoxides cysteine shows that the cysteine derivative by enzymatic process of C-S lyase enzyme produces four thiosulfinates. Four thiosulfinate produced from the enzymatic process, (Z)-thiobenzaldehyde S-oxides-thiosulfinates, were the main compounds containing sulfur components. Further studies produced thiosul-finates derivatives, which are (Z)-thiobenzal-ehyde soxide, benzyl thiosulfinates, tri-sulfides, and benzylsulfinic acid. The benzyl thio-sulfinates compound is relatively the strongest of its antibacterial activity. It is reported to have activity in reducing the fluidity of the membrane, also reported to have inhibitory activity against macromolecular syn-thesis such as DNA, RNA, cell walls and proteins (Kim et al 2006).

Pettiveria alliacea contains benzyl-thiosulfinate compounds that have the function of inhibiting the growth of Mycobacterium smegmatis bacteria by interfering the formation of cell walls, resulting in cell wall lysis (Ayodele et al 2000). The results of Ayodele et al's study reinforced previous studies showing that the extract of Singawalang leaf ethanol was able to inhibit the growth of various pathogenic bacteria, such as E. coli, staphylococcus, pseudomonas, and Shigela in vitro. The study by Kim et al explained that both water and etanol extracts of Pettiveria alliacea's leaves and roots are able to inhibit various bacteria from either group of gram positive bacteria or group of gram negative bacteria. In the study, each bacterium required different concentrations of extracts for the inhibitory power of certain bacterium. The bacteria used in the study were Bacillus cereus, Staphylococcus aureus, Micrococcus luteus, Mycobacterium smegmatis, Streptococcus agalactiae, Escherichia coli, Pseudomonas aeruginosa, Kleibsiella pneumoniase and Stenotrophomonas maltophila. In addition to various bacteria, the study also proved that the plant was also able to inhibit the growth of various fungi in vitro. (Kim et al 2005). Aside from various bacteria, the study also proved that the plant was also able to inhibit the growth of various fungi in vitro. (Kim et al 2005). Differences in results may occur due to differences in the way of extraction was done and sample preparation was made. In this study, Singawalang leaf ethanol extract was extracted by maceration without being heated. Kim at al.'s study also did the same procedure in extracting singawalang leaf ethanol. While in Torre's study, extraction was carried out after heated in water or alcohol. The difference in extraction procedures may cause the active ingredients contained in the leaves Singawalang be reduced or even be lost because some of the active ingredients' structures may be damaged or changed due to heating, thus, the study results are different. The differences in study results may also be due to differences in areas where plants grow. Nutrient content may affect the amount of plant's active 
ingredients, so the amount of active ingre-dients may also be reduced.

\section{CONCLUSION}

Mycobacterium tuberculosis colony growth profile on control treatment, $1 \%$ DMSO treatment and $1 \%$ alcohol treatment with singawalang leaf extract with various solvents in $2 \mathrm{mg} / \mathrm{ml}$ dose had different growth number of bacterial colonies. The highest number of Mycobacterium tuberculosis colonies was found in the control treatment, $1 \%$ DMSO treatment and 1\% alcohol treatment, while the reduction of $\mathrm{Myco}-$ bacterium tuberculosis colony growth rate occured in treatment with Singawalang leaf extract with various solvents. There was no significant difference in $\mathrm{Myco-}$ bacterium tuberculosis colony growth between control and treatment, and 1\% DMSO treatment and $1 \%$ alcohol treatment. There was no significant difference in the growth of Mycobacterium tuberculosis colonies treated with ethanol extract of Singawalang with various solvents.

\section{REFERENCES}

Aditama TY (2011). 'Programmatic management of drug resistance tuberculosis, Rencana aksi nasional', Kementerian Kesehatan RI, Jakarta, p 117

Ayodele ET, Hudson HR, Ojo IAO, et al (2000). Organosulfur compounds as potential fungicides: the preparation and properties of some substituted benzyl 2-hydroxyethyl oligosulfides. Phosphorus Sulfur Silicon and Related Elements Vol 159, 123-142

Global Tuberculosis Report (2016). World Health Organisation

Kim S, Kubec R, Musah RA (2006). Antibacterial and anti fungal activity of sulfur containing compound from petiveria alliacea. J. Ethnopharmacology Vol $104(1-2), 188-92$ 